\title{
Development and Validation of Visible Spectrophotometric Methods for the Analysis of Etravirine: Application to Tablet Dosage Forms
}

\section{Murali Dadi ${ }^{1 *}$, Indra Sen Singh ${ }^{1}$ and G Purna Chandra Rao $^{2}$}

${ }^{1}$ Department of Chemistry, Copperbelt University, Jambo Drive, Kitwe, Zambia

${ }^{2}$ Department of Chemistry, NRI Institute of Technology, Pothavarpadu, Agiripalli, Andhra Pradesh, India

*Corresponding Author: Murali Dadi, Department of Chemistry, Copperbelt University, Jambo Drive, Kitwe, Zambia.
Received: April 17, 2020

Published: June 15, 2020

(C) All rights are reserved by Murali Dadi., et al.

\section{Abstract}

The present study describes the development and validation of two simple, sensitive, accurate, precise and economical spectrophotometric methods for the estimation of Etravirine (ETR) in bulk and its tablet dosage forms. These methods have developed based on the diazotization of ETR followed by coupling with alkaline $\beta$-naphthol (Method-A) and p-nitro aniline in alkaline medium (Method-B). These methods show a linear relation between absorbance and concentration of ETR in the ranges of $5-30 \mu \mathrm{g} / \mathrm{mL}(\mathrm{M}-$ A) and 2.5 - $15 \mu \mathrm{g} / \mathrm{mL}(\mathrm{M}-\mathrm{B})$ respectively. The Molar absorptive for present methods are $3.685 \times 10^{3}(\mathrm{M}-\mathrm{A})$ and $5.614 \times 10^{4}(\mathrm{M}-\mathrm{B})$ and LOD, LOQ values are $0.656 \mu \mathrm{g} / \mathrm{mL}, 1.990 \mu \mathrm{g} / \mathrm{mL}(\mathrm{M}-\mathrm{A})$ and $0.191 \mu \mathrm{g} / \mathrm{mL}, 0.578 \mu \mathrm{g} / \mathrm{mL}(\mathrm{M}-\mathrm{B})$ respectively. The common excipients in the drug did not interfere in the estimation process and the developed methods are successfully applied to tablet dosage forms of ETR.

Keywords: Etravirine; $\beta$-Naphthol; p-Nitro Aniline; Alkaline Medium; Spectrophotometry

\section{Introduction}

Etravirine is an antiretroviral agent more specifically classified as a Non-Nucleoside Reverse Transcriptase Inhibitor (NNRTI). Etravirine (Figure 1) exerts its TEMP effects via direct inhibition of the reverse transcriptase enzyme of human immunodeficiency virus type 1 (HIV-1). It directly binds reverse transcriptase and consequently blocks DNA-dependent and RNA-dependent polymerase activity. Etravirine does not inhibit human DNA polymerase alpha, beta or gamma [1]. Chemically it is 4-(\{6-amino-5-bromo-2-[(4cyanophenyl) amino] pyrimidin-4-yl\} oxy)-3, 5-dimethylbenzonitrile with M.W. 435.277. The literature survey on ETR revealed that various HPLC [2-6], HPLC-MS [7], HPLC-MS/MS [8], HPTLC [9], LC-MS/MS [10], LC-ESI-MS [11], LC-tandem MS [12,13], UPLC [14], UPLC-MS/MS [15,16] and UV spectrophotometric [17,18] have been reported for estimation of ETR. The reported HPLC, HPLC-MS, HPLC-MS/MS, HPTLC, LC-MS/MS and UPLC methods need sophisticated laboratory, more costly reagents, expensive instrumentation and these take much time to analysis. The reported UV Visible spectrophotometric methods are less selective and the measured absorbance at shorter wave lengths and these methods have developed by using reagents other than $\beta$-Naphthol, p-nitro aniline. Hence, it is need to development and validation of simple, selec-<smiles>Cc1cc(C#N)cc(C)c1Oc1nc(Nc2ccc(C#N)cc2)nc(N)c1Br</smiles>

Figure 1: Chemical structure of Etravirine.

tive, precise, cost-effective spectrophotometric methods by using $\beta$-naphthol, p-nitro aniline as analytical reagents.

\section{Materials and Methods}

\section{Materials}

An ELICO (Hyderabad, India) double beam model SL 244 digital spectrophotometer was used for spectrophotometric measure- 
ments and $1 \mathrm{~cm}$ matched quartz cells were used for measurements and Coslab (Ambala Cantt, India) CLE-105 model water bath was used to control the temperature. All chemicals were of analytical reagent grade. Double distilled water was used to prepare all solutions. All 45the solutions were prepared a fresh daily.

\section{Method (M-A)}

1. $2 \mathrm{~N} \mathrm{HCl}(\mathrm{v} / \mathrm{v})$ : Prepared by diluting $17.2 \mathrm{ml}$ of concentrated $\mathrm{HCl}$ to $1000 \mathrm{ml}$ with distilled water. This solution was standardized.

2. $0.1 \%(\mathrm{w} / \mathrm{v})$ sodium nitrite: Prepared by dissolving $100 \mathrm{mg}$ of $\mathrm{NaNO}_{2}$ in $100 \mathrm{ml}$ distilled water.

3. $2 \%(\mathrm{w} / \mathrm{v})$ sodium hydroxide: Prepared by dissolving $2 \mathrm{gm}$ $\mathrm{NaOH}$ in $100 \mathrm{ml}$ distilled water.

4. $0.1 \%(\mathrm{w} / \mathrm{v})$ alkaline $\beta$-naphthol: Prepared by dissolving 100 mg of $\beta$-naphthol in $2 \% \mathrm{NaOH}$ solution.

\section{Method (M-B)}

1. $0.2 \mathrm{M} \mathrm{HCl}(\mathrm{v} / \mathrm{v})$ : Prepared by diluting $17.2 \mathrm{ml}$ of concentrated $\mathrm{HCl}$ to $1000 \mathrm{ml}$ with distilled water.

2. $0.1 \% \mathrm{p}$-nitro aniline (PNA): Prepared by dissolving $100 \mathrm{mg}$ of PNA in $100 \mathrm{ml}$ of $0.2 \mathrm{M} \mathrm{HCl}$.

3. $0.4 \%(\mathrm{w} / \mathrm{v})$ sodium nitrite: Prepared by dissolving $400 \mathrm{mg}$ of $\mathrm{NaNO}_{2}$ in $100 \mathrm{ml}$ distilled water.

4. $4 \%(\mathrm{w} / \mathrm{v})$ sodium hydroxide: Prepared by dissolving $4 \mathrm{gm}$ $\mathrm{NaOH}$ in $100 \mathrm{ml}$ distilled water.

\section{Preparation of stock and working standard solutions}

Stock solution of ETR was prepared by dissolving $100 \mathrm{mg}$ of drug in $20 \mathrm{ml}$ of methanol in a $100 \mathrm{ml}$ volumetric flask and then make up to the mark with distilled water $(1.0 \mathrm{mg} / \mathrm{ml})$. The stock solution was diluted stepwise with the distilled water to obtain working standard solutions of concentration $100 \mu \mathrm{g} / \mathrm{ml}(\mathrm{M}-\mathrm{A})$ and $50 \mu \mathrm{g} / \mathrm{ml}(\mathrm{M}-\mathrm{B})$ respectively.

General assay procedure

Method (M-A)

Delivered aliquots (0.5 - $3.0 \mathrm{ml})$ of standard ETR solution (100 $\mu \mathrm{g} / \mathrm{ml}$ ) into a series of $10 \mathrm{ml}$ calibrated tubes. To each tube 1.0 $\mathrm{ml}$ of $2 \mathrm{~N} \mathrm{HCl}$ and $1.0 \mathrm{ml}$ of $0.1 \% \mathrm{NaNO}_{2}$ were added. The contents were subjected to cooling at $0-5^{\circ} \mathrm{C}$ for 10 minutes. After cooling, to each tube $1.0 \mathrm{ml}$ of $0.1 \%$ alkaline $\beta$-naphthol was added and gently shaken. The tubes are kept aside for 10 minutes. The volume in each tube was made up to the mark and the absorbance of the colored solution was measured at $540 \mathrm{~nm}$ against a reagent blank. The amount of drug was deduced from its calibration curve (Figure 2).

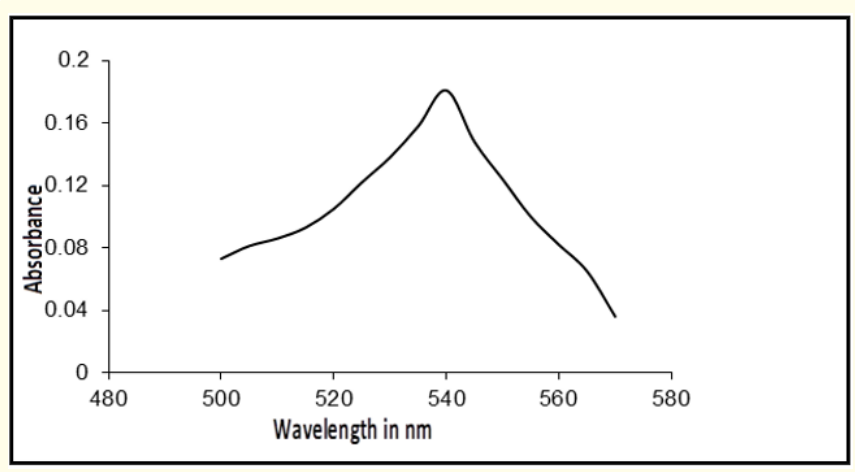

Figure 2: Absorption spectrum of ETR- $\beta$-naphthol.

\section{Method (M-B)}

Delivered aliquots $(0.5-3.0 \mathrm{ml})$ of standard ETR solution (50 $\mu \mathrm{g} / \mathrm{ml}$,) into a series of $10 \mathrm{ml}$ calibrated tubes. To each tube $0.8 \mathrm{ml}$ of $0.1 \%$ PNA followed by $1.0 \mathrm{ml}$ of $0.4 \% \mathrm{NaNO}_{2}$ were added and the tubes were kept aside for 20 minutes. To each tube $2.0 \mathrm{ml}$ of $4 \% \mathrm{NaOH}$ was added and kept aside for 30 minutes. The volume in each tube was made up to the mark with distilled water and the absorbance was measured at $420 \mathrm{~nm}$ against a reagent blank. The amount of drug was computed from its calibration curve (Figure 3 ).

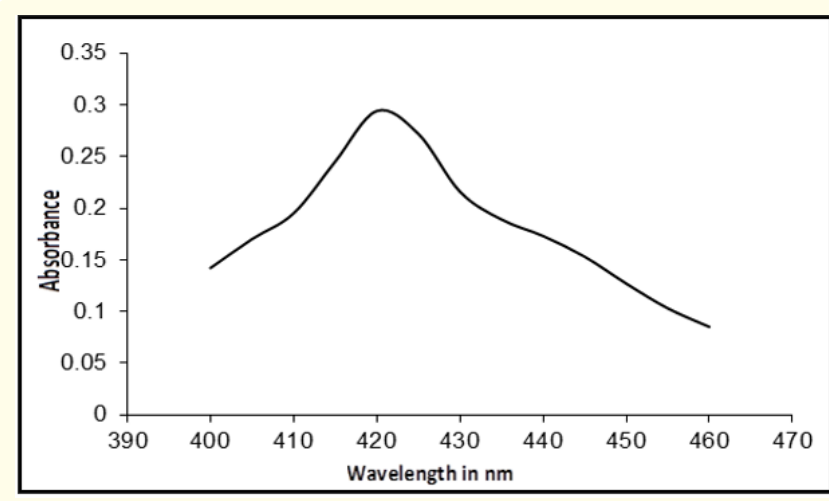

Figure 3: Absorption spectrum of ETR-PNA.

\section{Assay of ETR in tablet dosage form}

Intelence tablets (Janssen Pharmaceuticals, Inc., Titusville NJ) were labeled to contain $100 \mathrm{mg} / 200 \mathrm{mg}$ ETR per tablet were used in the present investigation. Twenty tablets were weighed and finely powdered. An accurately weighed quantity of the powder equivalent to $100 \mathrm{mg}$ of ETR was transferred into a $100 \mathrm{ml}$ calibrated flask and dissolved in about $20 \mathrm{ml}$ of methanol. The contents of the flask were swirled, sonicated for 10 minutes and filtered through Whatman No. 1 filter paper. The filtrate was completed to volume with distilled water. This solution was diluted quantitatively with distilled water to obtain suitable concentrations for the analysis 
by the proposed spectrophotometric methods (M-A and M-B). The content of ETR in the tablets was calculated from the corresponding calibration curve or corresponding regression equation.

\section{Results and Discussion}

Optimization of experimental conditions

The experimental variables in the present proposed spectrophotometric methods (M-A and M-B), which are found to affect the color intensity and stability of the resulting colored complexes, were optimized to achieve maximum sensitivity and adherence to Beer's law. The following experiments were conducted for this purpose and the conditions so obtained were incorporated in general assay procedures.

\section{Method (M-A)}

This method is based on the diazotization of ETR under acidic conditions followed by its coupling with the alkaline $\beta$-naphthol.
The experimental conditions were established by studying the effect of various parameters like acidity, volume and concentrations of $\mathrm{NaNO}_{2}$, alkaline $\beta$-naphthol, diazotization time and diazocoupling time for the maximum and stable color development. The results are incorporated in table 1.

\section{Method (M-B)}

In this method diazotization of PNA takes place under acidic conditions followed by its coupling with the ETR. The experimental conditions were established by studying the effect of various parameters like acidity, volume and concentrations of $\mathrm{PNA}, \mathrm{NaNO}_{2}$ and $\mathrm{NaOH}$ for the stable color development and the time required for diazotization and diazocoupling. The results are incorporated in table 2 .

\section{Determination of absorption maxima $\left(\lambda_{\max }\right)$}

To determine the analytic wavelength, the absorption spectra of the colored chromogens formed in the proposed methods (M-A

\begin{tabular}{|c|c|c|c|}
\hline Parameter & Investigation conditions & Optimized condition & Remarks \\
\hline$\lambda_{\max }(\mathrm{nm})$ & $500-600$ & 540 & \\
\hline Volume of $2 \mathrm{~N} \mathrm{HCl}(\mathrm{ml})$ & $0.5-5.0$ & 1.0 & $\begin{array}{c}\text { Increasing volume of } \mathrm{HCl} \text { produces an increase } \\
\text { in the absorbance upto } 1.0 \mathrm{ml} \text {. Beyond this } \\
\text { volume a gradual decrease in the absorbance is } \\
\text { observed. }\end{array}$ \\
\hline Volume of $0.1 \% \mathrm{NaNO}_{2}(\mathrm{ml})$ & $0.5-5.0$ & 1.0 & $1.0 \mathrm{ml}$ of $\mathrm{NaNO}_{2}$ was sufficient to diazotize ETR \\
\hline $\begin{array}{l}\text { Reaction time for } \\
\text { diazotization (min) }\end{array}$ & $5-25$ & 10 & $\begin{array}{l}\text { Diazotization goes to almost completion within } \\
10 \text { min. So, } 10 \text { min was chosen as optimum time. }\end{array}$ \\
\hline $\begin{array}{c}\text { Volume of } 0.1 \% \text { alkaline } \beta \\
\text { Napthol }(\mathrm{ml})\end{array}$ & $0.5-5.0$ & 1.0 & $\begin{array}{l}\text { The maximum absorbance was reached with } 1.0 \\
\text { ml of } \beta \text {-napthol. }\end{array}$ \\
\hline $\begin{array}{l}\text { Reaction time for } \\
\text { diazocoupling (min) }\end{array}$ & $5-20$ & 10 & $\begin{array}{l}\text { Diazocoupling was completed at } 10 \mathrm{~min} \text {. So, } 10 \\
\text { min was chosen as optimum time. }\end{array}$ \\
\hline
\end{tabular}

Table 1: Optimization of conditions for the assay of ETR by method M-A.

\begin{tabular}{|c|c|c|c|}
\hline Parameter & Investigation conditions & Optimized condition & Remarks \\
\hline$\lambda_{\max }(\mathrm{nm})$ & $400-500$ & 420 & \\
\hline Volume of $0.1 \%$ PNA (ml) & $0.2-2.0$ & 0.8 & $\begin{array}{l}\text { It was found that maximum and stable color was } \\
\text { formed with } 0.8 \mathrm{ml} \text { of PNA in final volume of } 10 \\
\text { ml. }\end{array}$ \\
\hline Volume of $0.4 \% \mathrm{NaNO}_{2}(\mathrm{ml})$ & $0.5-5.0$ & 1.0 & $1.0 \mathrm{ml}$ of $\mathrm{NaNO}_{2}$ was required to diazotize PNA \\
\hline $\begin{array}{l}\text { Reaction time for } \\
\text { diazotization (min) }\end{array}$ & $5-30$ & 20 & $\begin{array}{l}\text { Diazotization goes to almost completion within } \\
20 \mathrm{~min} \text {. So, } 20 \text { min was chosen as optimum time. }\end{array}$ \\
\hline Volume of $4 \% \mathrm{NaOH}(\mathrm{ml})$ & $0.5-5.0$ & 2.0 & $\begin{array}{c}2.0 \mathrm{ml} \text { of } \mathrm{NaOH} \text { gave maximum absorbance and } \\
\text { therefore } 2.0 \mathrm{ml} \text { of } \mathrm{NaOH} \text { was chosen. }\end{array}$ \\
\hline $\begin{array}{l}\text { Reaction time for diazocou- } \\
\text { pling (min) }\end{array}$ & $10-50$ & 30 & $\begin{array}{l}\text { Diazocoupling was completed at } 30 \mathrm{~min} \text {. So, } 30 \\
\text { min was chosen as optimum time. }\end{array}$ \\
\hline
\end{tabular}

Table 2: Optimization of conditions for the assay of ETR by method M-B. 
and M-B) were scanned in the wavelength region of $400-700 \mathrm{~nm}$ against a corresponding reagent blank. The results are graphically presented in the figure 2 and 3.

\section{Method validation}

The proposed methods (M-A and M-B) were validated for linearity, sensitivity, selectivity, stability of the colored species, accuracy, precision, robustness and recovery according to the current ICH guidelines.
Linearity and sensitivity

Under the optimum conditions, a linear relation was obtained between absorbance and concentration of ETR in the ranges given in table 3. The calibration graphs (Figure 4 and 5) in each instance is described by the equation: $\mathrm{Y}=\mathrm{c}+\mathrm{mX}$, (where $\mathrm{Y}=$ absorbance, $\mathrm{c}$ = intercept, $\mathrm{m}=$ slope and $\mathrm{X}=$ concentration of ETR in $\mu \mathrm{g} / \mathrm{ml}$ ). The regression coefficient, intercept and slope for the calibration data are summarized in table 3 . The values specify that there is a good correlation between absorbance values and concentration of ETR in the proposed methods.

\begin{tabular}{|c|c|c|c|c|c|}
\hline $\begin{array}{c}\text { Parameter } \\
\text { Method }\end{array}$ & $\begin{array}{l}\text { Linearity range } \\
(\mu \mathrm{g} / \mathrm{ml})\end{array}$ & $\begin{array}{l}\text { Regression equation } \\
\qquad(Y=m x+c)^{*}\end{array}$ & $\begin{array}{c}\text { Regression coefficient } \\
\left(\mathbf{R}^{2}\right)\end{array}$ & $\begin{array}{l}\text { Slope } \\
\text { (m) }\end{array}$ & $\begin{array}{l}\text { Intercept } \\
\text { (c) }\end{array}$ \\
\hline M-A & $5-30$ & $Y=0.0870 x+0.0051$ & 0.9989 & 0.0870 & 0.0051 \\
\hline M-B & $2.5-15$ & $Y=0.0289 x+0.0042$ & 0.9993 & 0.0289 & 0.0042 \\
\hline
\end{tabular}

Table 3: Linearity and regression parameters of the proposed spectrophotometric methods.

$* \mathrm{Y}=$ Absorbance; $\mathrm{x}=$ Concentration of drug in $\mu \mathrm{g} / \mathrm{ml}$.

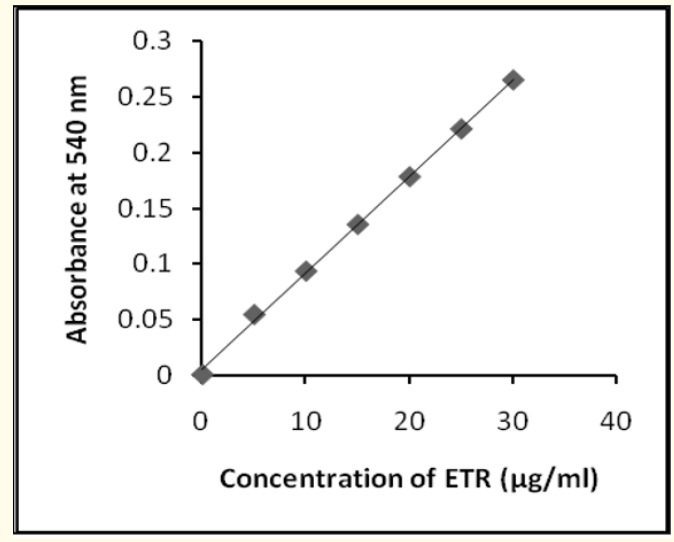

Figure 4: Beer's law plot of ETR- $\beta$-naphthol

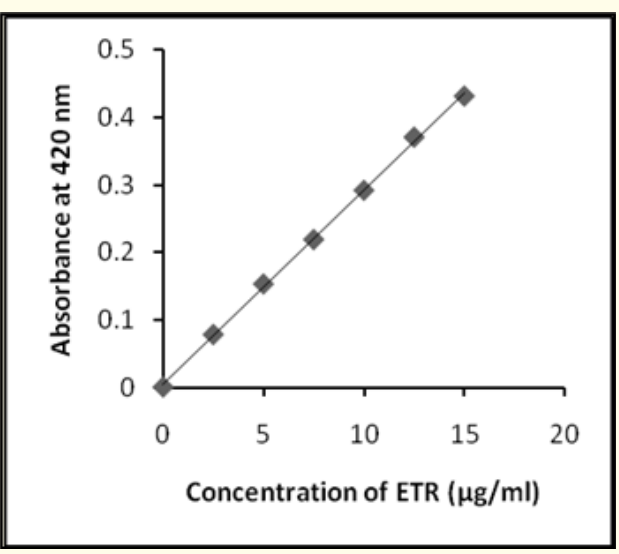

Figure 5: Beer's law plot of ETR-PNA.
Sensitivity parameters such as apparent molar absorptivity and Sandell's sensitivity values, the limits of detection (LOD) and quantification (LOQ) are calculated as per the current ICH guidelines and compiled in table 4 . The values indicated that the proposed methods (M-A and-M-B) have adequate sensitivity for the analysis of ETR.

Accuracy and precision

To determine the accuracy and precision of the proposed methods, pure ETR solution at three different concentration levels (M-A - 5,15 and $30 \mu \mathrm{g} / \mathrm{ml}$; M-B - 2.5,7.5 and $15 \mu \mathrm{g} / \mathrm{ml}$ ) were prepared and analyzed in five replicates during the same day (intra-day precision) and on three consecutive days (inter-day precision) by the proposed methods (M-A-M-B). The results are presented in table 5 and 6 . The reported values in tables give the information that the accuracy of the proposed methods is satisfactory and the low values indicating repeatability of the proposed methods in the routine analysis of ETR.

\section{Recovery studies}

The accuracy and validity of the proposed methods were further demonstrated by performing recovery studies. Pre analyzed tablet powder was spiked with pure ETR at three concentration levels $(50,100$ and $150 \%)$ and the total concentration was once again analyzed by the proposed methods (M-A and M-B). The results of this study are presented in table 7. The percent recovery of the ETR is in the range of $99.88-99.94 \%$, and $99.04-99.92 \%$ for the methods M-A and M-B, respectively. The good percentage of recovery values indicate that the excipients present in the tablets did not interfere 


\begin{tabular}{|c|c|c|c|c|}
\hline Parameter & $\begin{array}{c}\text { Molar Absorptivity } \\
\text { Method }\end{array}$ & $\begin{array}{c}\text { Sandell's sensitivity } \\
\left(\boldsymbol{L} / \mathbf{m o l} \mathbf{~ c m}^{-2} \mathbf{~} \mathbf{c m}\right)\end{array}$ & $\begin{array}{c}\text { LOD } \\
(\boldsymbol{\mu} \mathbf{g} / \mathbf{m l})\end{array}$ & $\begin{array}{c}\text { LOQ } \\
(\boldsymbol{\mu} \mathbf{g} / \mathbf{m l})\end{array}$ \\
\hline M-A & $3.685 \times 10^{3}$ & 1.1310 & 0.656 & 1.990 \\
\hline M-B & $5.614 \times 10^{4}$ & 0.3424 & 0.191 & 0.578 \\
\hline
\end{tabular}

Table 4: Sensitivity and stability parameters of the proposed spectrophotometric methods.

\begin{tabular}{|c|c|c|c|c|c|c|c|}
\hline \multirow{2}{*}{ Method } & \multicolumn{2}{|c|}{ Concentration of ETR $(\mu \mathrm{g} / \mathbf{m l})$} & \multirow{2}{*}{ SD } & \multirow{2}{*}{$\begin{array}{c}\text { RSD } \\
\text { (\%) }\end{array}$} & $\begin{array}{c}\text { Recovery } \\
\text { (\%) }\end{array}$ & \multicolumn{2}{c|}{ Confidence limit } \\
\cline { 2 - 6 } & Taken & Found & & $\mathbf{0 . 0 5}$ & $\mathbf{0 . 0 1}$ \\
\hline \multirow{3}{*}{ M-A } & 5 & 4.988 & 0.02216 & 0.444 & 99.76 & 0.01852 & 0.02741 \\
\cline { 2 - 7 } & 15 & 14.995 & 0.03108 & 0.207 & 99.96 & 0.02598 & 0.03844 \\
\cline { 2 - 8 } & 30 & 30.001 & 0.02985 & 0.099 & 100.00 & 0.02495 & 0.03692 \\
\hline \multirow{2}{*}{ M-B } & 2.5 & 2.503 & 0.02727 & 0.108 & 100.12 & 0.00228 & 0.00337 \\
\cline { 2 - 7 } & 7.5 & 7.506 & 0.02349 & 0.312 & 100.08 & 0.00196 & 0.00290 \\
\cline { 2 - 7 } & 15 & 14.996 & 0.03124 & 0.208 & 99.97 & 0.00261 & 0.00386 \\
\hline
\end{tabular}

Table 5: Evaluation of intra-day precision and accuracy of the proposed spectrophotometric methods.

$*$ : Average of five determinations.

\begin{tabular}{|c|c|c|c|c|c|c|c|}
\hline \multirow{2}{*}{ Method } & \multicolumn{2}{|c|}{ Concentration of ETR $(\mu \mathrm{g} / \mathbf{m l})$} & \multirow{2}{*}{ SD } & \multirow{2}{*}{ RSD(\%) } & \multirow{2}{*}{ Recovery(\%) } & \multicolumn{2}{|c|}{ Confidence limit } \\
\cline { 2 - 6 } & Taken & Found & & & $\mathbf{0 . 0 5}$ & $\mathbf{0 . 0 1}$ \\
\hline \multirow{3}{*}{ M-A } & 5 & 4.970 & 0.02576 & 0.518 & 99.40 & 0.02153 & 0.03186 \\
\cline { 2 - 7 } & 15 & 14.986 & 0.03286 & 0.219 & 99.90 & 0.02747 & 0.04065 \\
\cline { 2 - 7 } & 30 & 29.996 & 0.02097 & 0.069 & 99.98 & 0.01753 & 0.02594 \\
\hline \multirow{2}{*}{ M-B } & 2.5 & 2.476 & 0.03155 & 1.274 & 99.04 & 0.00263 & 0.00390 \\
\cline { 2 - 7 } & 7.5 & 7.50 & 0.01979 & 0.263 & 100.00 & 0.01654 & 0.02448 \\
\cline { 2 - 7 } & 15 & 14.988 & 0.02126 & 0.141 & 99.92 & 0.01777 & 0.02630 \\
\hline
\end{tabular}

Table 6: Evaluation of inter-day precision and accuracy of the proposed spectrophotometric methods.

*: Average of five determinations.

\begin{tabular}{|c|c|c|c|c|c|c|c|}
\hline \multirow[t]{2}{*}{ Method } & \multirow{2}{*}{$\begin{array}{c}\text { Spiked } \\
\text { level }\end{array}$} & \multicolumn{3}{|c|}{ Concentration of ETR $(\mu \mathrm{g} / \mathrm{ml})$} & \multirow[t]{2}{*}{ SD } & \multirow{2}{*}{$\begin{array}{l}\text { RSD } \\
(\%)\end{array}$} & \multirow{2}{*}{$\begin{array}{c}\text { Recovery } \\
\text { (\%) }\end{array}$} \\
\hline & & Taken & Spiked & Found* & & & \\
\hline \multirow[t]{3}{*}{ M-A } & 50 & 5 & 2.5 & 7.491 & 0.00907 & 0.121 & 99.88 \\
\hline & 100 & 5 & 5 & 9.994 & 0.01608 & 0.160 & 99.94 \\
\hline & 150 & 5 & 7.5 & 12.493 & 0.01410 & 0.112 & 99.94 \\
\hline \multirow[t]{3}{*}{ M-B } & 50 & 2.5 & 1.25 & 3.742 & 0.03155 & 1.274 & 99.04 \\
\hline & 100 & 2.5 & 2.5 & 4.997 & 0.03215 & 0.859 & 99.78 \\
\hline & 150 & 2.5 & 5 & 7.494 & 0.01401 & 0.186 & 99.92 \\
\hline
\end{tabular}

Table 7: Results of recovery studies of the proposed spectrophotometric methods.

*: Average of three determinations.

in the assay. The non-interference of excipients also demonstrates the selectivity of the proposed methods.

\section{Robustness}

To evaluate the robustness of the proposed spectrophotometric methods, the experimental variables were altered deliberately and the effect of these change on the performance of the proposed methods (M-A and M-B) were studied. The robustness of the methods was studied at two different concentration levels (M-A - 5 and $30 \mu \mathrm{g} / \mathrm{ml}$; and M-B - 2.5 and $15 \mu \mathrm{g} / \mathrm{ml}$ ). The results of this study are presented in table 8 . From the \%RSD values presented in table 8 


\begin{tabular}{|c|c|c|c|c|c|c|}
\hline \multirow[t]{2}{*}{ Method } & \multirow[t]{2}{*}{ Parameter } & \multicolumn{2}{|c|}{ Concentration of ETR $(\mu \mathrm{g} / \mathrm{ml})$} & \multirow[t]{2}{*}{ SD } & \multirow{2}{*}{$\begin{array}{c}\text { Recovery } \\
\text { (\%) }\end{array}$} & \multirow{2}{*}{$\begin{array}{l}\text { RSD } \\
\text { (\%) }\end{array}$} \\
\hline & & Taken & Found* & & & \\
\hline \multirow{10}{*}{ M-A } & \multirow{2}{*}{ Volume of $0.2 \mathrm{~N} \mathrm{HCl}(1.0 \pm 0.1 \mathrm{ml})$} & 5 & 4.99 & 0.0122 & 99.80 & 0.245 \\
\hline & & 30 & 29.98 & 0.0316 & 99.93 & 0.105 \\
\hline & \multirow{2}{*}{ Volume of $0.1 \% \mathrm{NaNO}_{2}(1.0 \pm 0.1 \mathrm{ml})$} & 5 & 5.03 & 0.0644 & 100.60 & 1.280 \\
\hline & & 30 & 30.03 & 0.0561 & 100.10 & 0.186 \\
\hline & \multirow{2}{*}{ Volume of $0.1 \% \beta$ Naphthol $(1.0 \pm 0.1 \mathrm{ml})$} & 5 & 4.98 & 0.0367 & 99.60 & 0.737 \\
\hline & & 30 & 30.01 & 0.0357 & 100.03 & 0.118 \\
\hline & \multirow{2}{*}{ Diazotization time $(10 \pm 2 \mathrm{~min})$} & 5 & 5.01 & 0.0406 & 100.20 & 0.810 \\
\hline & & 30 & 30.01 & 0.0433 & 100.03 & 0.144 \\
\hline & \multirow{2}{*}{ Diazo coupling time $(10 \pm 2 \mathrm{~min})$} & 5 & 4.98 & 0.0269 & 99.60 & 0.540 \\
\hline & & 30 & 29.98 & 0.0367 & 99.93 & 0.122 \\
\hline \multirow{10}{*}{ M-B } & \multirow{2}{*}{ Volume of $0.1 \%$ PNA $(0.8 \pm 0.1 \mathrm{ml})$} & 2.5 & 2.49 & 0.0254 & 99.60 & 1.023 \\
\hline & & 15 & 15.01 & 0.0295 & 100.06 & 0.197 \\
\hline & \multirow{2}{*}{ Volume of $0.4 \% \mathrm{NaNO}_{2}(1.0 \pm 0.1 \mathrm{ml})$} & 2.5 & 2.51 & 0.0229 & 100.40 & 0.912 \\
\hline & & 15 & 15.01 & 0.0285 & 100.06 & 0.197 \\
\hline & \multirow{2}{*}{ Volume of $4 \% \mathrm{NaOH}(1.0 \pm 0.2 \mathrm{ml})$} & 2.5 & 2.49 & 0.0187 & 99.60 & 0.751 \\
\hline & & 15 & 14.98 & 0.0300 & 99.86 & 0.200 \\
\hline & \multirow{2}{*}{ Diazotization time $(20 \pm 2 \mathrm{~min})$} & 2.5 & 2.51 & 0.0357 & 100.40 & 1.422 \\
\hline & & 15 & 15.02 & 0.0374 & 100.13 & 0.249 \\
\hline & \multirow{2}{*}{ Diazo coupling time $(30 \pm 2 \mathrm{~min})$} & 2.5 & 2.51 & 0.0229 & 100.40 & 0.912 \\
\hline & & 15 & 15.01 & 0.0295 & 100.06 & 0.197 \\
\hline
\end{tabular}

Table 8: Robustness of the proposed spectrophotometric methods.

*Average of three determinations.

(0.105 - $1.280 \%, 0.197-1.422 \%$ for methods M-A and M-B, respectively) one can conclude that the proposed methods are robust.

\section{Application to the tablet dosage forms}

The proposed methods (M-A and M-B) were successfully applied to the estimation of ETR in commercially available tablets (Intelence tablets, Janssen Pharmaceuticals, Inc., Titusville NJ, labeled to contain $100 \mathrm{mg} / 200 \mathrm{mg}$ ETR per tablet). The results are compiled in table 9 . The good percent recovery value with low relative standard deviation $(<1 \%)$ value confirms the suitability of the proposed methods (M-A and M-B) for the routine analysis of ETR in tablet dosage forms.

The results obtained were statistically compared with the labeled claim values by applying the Student's t-test for accuracy and F-test for precision at $95 \%$ confidence level. As can be seen from table 9 , the calculated $\mathrm{t}$ - and $\mathrm{F}$ - values at 0.05 confidence level did not exceed the tabulated values of 1.833 and 5.19 respectively. This indicates that the proposed methods possess sufficient accuracy and precision.

\section{Chemistry of the colored products}

\section{Method M-A}

The results obtained in method M-A were based on the diazotization of the ETR under acidic conditions, followed by its coupling with $\beta$-naphthol in alkaline medium to form a colored complex [19]. In method M4, initially ETR was converted to its diazonium salt with $\mathrm{NaNO}_{2}$ in the presence of $\mathrm{HCl}$. The reaction is usually carried out in an ice bath. The diazonium salt form of ETR couples with the $\beta$-naphthol in the presence of $\mathrm{NaOH}$ resulting in the formation of the colored azo-dye having maximum absorption at $540 \mathrm{~nm}$ against the corresponding reagent blank.

\section{Method M-B}

In this method, PNA was converted to the diazonium salts by treatment with $\mathrm{NaNO}_{2}$ in acidic medium. The reaction is usually carried out in an ice bath. The diazonium salt form of PNA couples with the ETR at alkaline $\mathrm{pH}$ resulting in the formation of the colored azo-dye having maximum absorption at $420 \mathrm{~nm}$ against the corresponding reagent blank [20]. 


\begin{tabular}{|c|c|c|c|c|c|c|c|}
\hline Method & Labeled claim (mg) & Found & SD & \% RSD & \% Recovery & $\boldsymbol{t}_{\text {-Value }}$ ** & F-Value*** \\
\hline \multirow{2}{*}{ M-A } & 200 & 199.99 & 0.02959 & 0.1477 & 99.99 & 0.1879 & 3.723 \\
\cline { 2 - 9 } & 100 & 100.12 & 0.02413 & 0.2406 & 100.33 & 0.2425 & 1.212 \\
\hline \multirow{2}{*}{ M-B } & 200 & 200.04 & 0.02577 & 0.1286 & 100.16 & 0.2265 & 2.085 \\
\cline { 2 - 9 } & 100 & 99.49 & 0.02590 & 0.2603 & 99.49 & 0.1548 & 2.6897 \\
\hline
\end{tabular}

Table 9: Assay of ETR in tablets by the proposed spectrophotometric methods.

*: Average of six determinations. *: Average of six determinations. **: Tabulated t value - 1.833. **: Tabulated $\mathrm{F}$ value - 5.19 .<smiles>Cc1cc(C#N)cc(C)c1Oc1cc(N)nc(CNc2ccc(C#N)cc2)n1</smiles>

Figure A

\section{Conclusion}

In the present investigation, the developed methods were validated by testing their linearity, sensitivity, accuracy, precision, selectivity and robustness and the statistical data from the validation studies demonstrated the methods to be accurate, precise, selective, sensitive, linear and robust. The procedures which have followed in the present investigation meet all the criteria of the demands of analytical chemists namely simplicity, accuracy, reliability and cost-effective analysis. Application of the proposed methods (M-A and M-B) was checked by analyzing with its formu- lations that revealed good recovery with low relative standard deviation values ensuring the suitability for routine quality control and drug analysis of ETR in tablet dosage forms.

\section{Acknowledgements}

The authors thankful to the university and NRI Institute of Technology to gave support and provide equipments and reagents to conduct present investigation. Authors also thank to the Arabindo Labs Pvt.Ltd., Hyderabad, India for providing pure drug as a gift sample. 


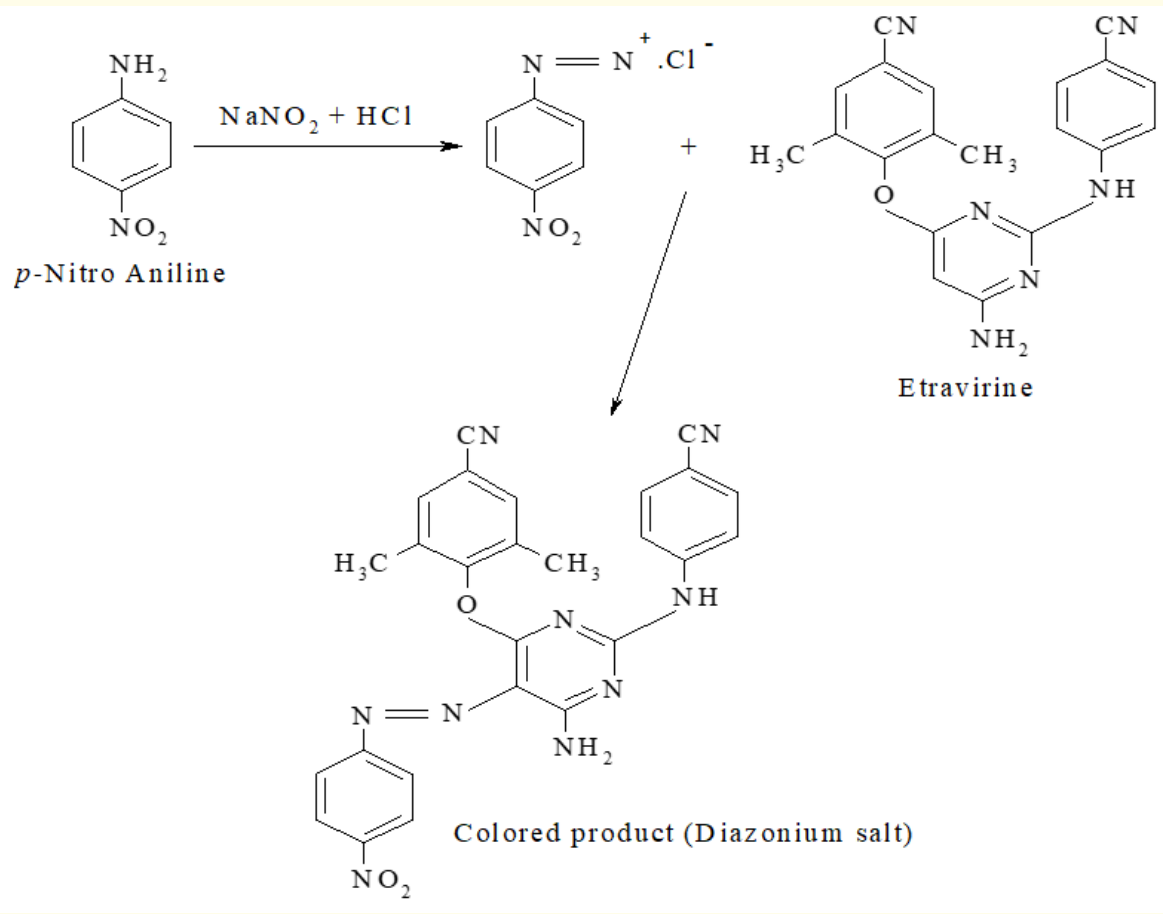

Figure B

\section{Conflict of Interest}

Authors do not have any conflict of interest for the present investigation.

\section{Bibliography}

1. Berma HM., et al. "The Protein Data Bank". Nucleic Acids Research 28.1 (2000): 235-242.

2. Satyanarayana L., et al. "The estimation of etravirine in tablet dosage form by RP-HPLC". Asian Journal of Research in Chemistry 4.10 (2011): 1649-1651.

3. Chinnalalaiah R and Kumar RP. "Development and validation of a new RP-HPLC method for estimation of etravirine in bulk and pharmaceutical dosage form". International Journal of Pharma Sciences 3.4 (2013): 291-294.

4. Babu GR., et al. "Development and validation of RP-HPLC method for quantitative analysis of etravirine in pure and pharmaceutical formulations". International Journal of Pharmacy 3.4 (2013): 747-752.

5. Murali D and Rambabu C. "Development and validation of stability indicating RP-HPLC method for the quantification of Etravirine in tablet dosage form". Der Pharmacia Lettre 7.12 (2015): 216-226
6. Thangabhalan B., et al. "Stability indicating RP-HPLC method for the estimation of etravirine in pure and tablet dosage form". International Journal of Pharmamedix India 1.4 (2013): 581-591.

7. D'Avolio A., et al. "HPLC-MS method for the quantification of nine anti-HIV drugs from dry plasma spot on glass filter and their long term stability in different conditions". Journal of Pharmaceutical and Biomedical Analysis 52.5 (2010): 774-780.

8. Else L., et al. "Validation of a rapid and sensitive high-performance liquid chromatography-tandem mass spectrometry (HPLC-MS/MS) assay for the simultaneous determination of existing and new antiretroviral compounds". Journal of Chromatography B 878.19 (2010): 1455-1465.

9. Raja AP and Venkateshwar RJ. "HPTLC method development and validation for determination of etravirine in bulk and tablet dosage form". International Journal of Pharmacy and Biological Sciences 3.3 (2013): 515-522.

10. Abobo CV., et al. "LC-MS/MS determination of etravirine in rat plasma and its application in pharmacokinetic studies". Journal of Chromatography B 878.30 (2010): 3181-3186. 
11. Rezk NZ., et al. "A novel LC-ESI-MS method for the simultaneous determination of etravirine, darunavir and ritonavir in human blood plasma". Talanta 79.5 (2009):1372-1378.

12. Fayet A., et al. "A LC-tandem MS assay for the simultaneous measurement of new antiretroviral agents: Raltegravir, maraviroc, darunavir and Etravirine". Journal of Chromatography $B$ 877.11-12 (2009): 1057-1069.

13. Heine R., et al. 'Quantification of Etravirine (TMC125) in plasma, dried blood spots and peripheral blood mononuclear cell lysate by liquid chromatography tandem mass spectrometry". Journal of Pharmaceutical and Biomedical Analysis 49.2 (2009): 393-400.

14. Reddy CM and Reddy KH. "A novel validated stability indicative UPLC method for Etravirine for the determination of process related and degradation impurities". American Journal of Analytical Chemistry 3.12 (2012): 840-848.

15. Aleem A. "Development and validation of stability indicating ultra performance liquid chromatographic method for Etravirine". International Journal of Pharmacy and Pharmaceutical Sciences 4.1 (2012): 255-261.

16. Djerada Z., et al. "Validation of a fast method for quantitative analysis of elvitegravir, raltegravir, maraviroc, etravirine, tenofovir, boceprevir and 10 other antiretroviral agents in human plasma samples with a new UPLC-MS/MS technology". Journal of Pharmaceutical and Biomedical Analysis 86 (2013): 100-111.

17. Reddaiah CV., et al. "Estimation of Etravirine by UV-Visible spectroscopic method in tablet dosage form and it's In vitro dissolution assessment". International Journal of Pharmacy Research and Development 4.3 (2012): 287-295.

18. Murali D., et al. "Spectrophotometric Determination of Etravirine in Bulk and Pharmaceutical formulations". American Journal of Analytical Chemistry 5 (2014): 77-82.

19. Ameera H Hamed. "Simple Method for Spectrophotometric Determination of Benzidine in Aqueous Solutions by Coupling with $\beta$-Naphthol". Journal of Al-Nahrain University 14.2 (2011): 43-50.

20. Nabeel S Othman and Nabil H Othman. "Spectrophotometric Determination of Teicoplanin via Coupling with Diazotized pNitro aniline". Rafidian Journal of Science 24.5 (2013): 42-51.

\section{Assets from publication with us}

- Prompt Acknowledgement after receiving the article

- Thorough Double blinded peer review

- Rapid Publication

- Issue of Publication Certificate

- High visibility of your Published work

Website: www.actascientific.com/

Submit Article: www.actascientific.com/submission.php Email us: editor@actascientific.com

Contact us: +919182824667 